\title{
Evolution of Dental Science in Ancient India
}

\section{K Chandrasekharan Nair ${ }^{1 *}$, MV Anil Kumar ${ }^{2}$ and Pradeep Dathan ${ }^{3}$}

${ }^{1}$ Professor Emeritus, Department of Prosthodontics, Sri Sankara Dental College, Akathumuri, Thiruvananthapuram, Kerala, India

${ }^{2}$ Superintendent and Professor, Women and Child Care Hospital, Govt Ayurveda College, Poojappura, Thiruvananthapuram, Kerala, India

${ }^{3}$ Professor and Head of the Department of Prosthodontics, Sri Sankara Dental

College, Akathumuri, Thiruvavananthapuram, Kerala, India

*Corresponding Author: K Chandrasekharan Nair, Professor Emeritus, Department of Prosthodontics, Sri Sankara Dental College, Akathumuri, Thiruvananthapuram, Kerala, India.
Received: November 15, 2021

Published: December 13, 2021

(C) All rights are reserved by

K Chandrasekharan Nair., et al.

\begin{abstract}
The legacy of Dentistry and Medicine can be traced to ancient literature like 'the Vedas'. Many drugs, predominantly of plant origin, prevention of diseases and maintenance of health can be found in the Vedas and masterly text books of Ayurveda. This article is an attempt to trace the origins of dental science in our ancient context. Master teachers of Ayurveda will find elaborate description in subsequent articles.
\end{abstract}

Keywords: Dentistry; History of Dentistry; Ancient Indian Dentistry

\section{Introduction}

The origin of ancient dentistry (Danta Sasthra) in India is synonymous with that of Ayurveda. Lord Brahma, the creator of the universe is considered to be the creator of Ayurveda and hence that of ancient dentistry. Brahma is traditionally depicted with four faces and four arms. Each face of his, points to a cardinal direction. He is often called Chaturanana/Chaturmukha (fourfaced) and Ashtakarna (eight-eared). His hands hold no weapons, rather symbols of knowledge and creation. In one hand he holds the sacred texts of Vedas, in the second he holds a mala (rosary beads) symbolizing time, in the third he holds a ladle (long handled spoon) symbolizing means to nurture sacrificial fire and in the fourth a kamandalu (utensil with water) symbolizing creation. His four mouths are credited with creating the four Vedas. He is often depicted with a white beard, implying his sage-like status. He sits on a lotus, dressed in white (or red, pink), with his vehicle Hansa (swan) nearby. Brahma may also be depicted as sitting on the sacred lotus flower which springs from Vishnu's navel. Other than the Vedas, Brahma is responsible for the creation of all branches of knowledge, music, yoga, religious acts, speech, Sanskrit, the various units of measurement and time (Figure 1,2).

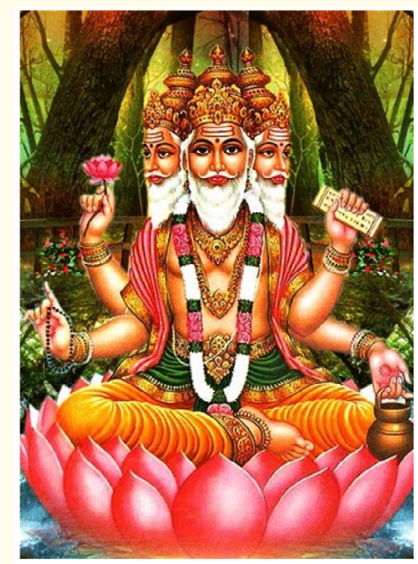

Figure 1: Lord Brahma.

(https://glorioushinduism.com/2016/12/02/brahma/) 


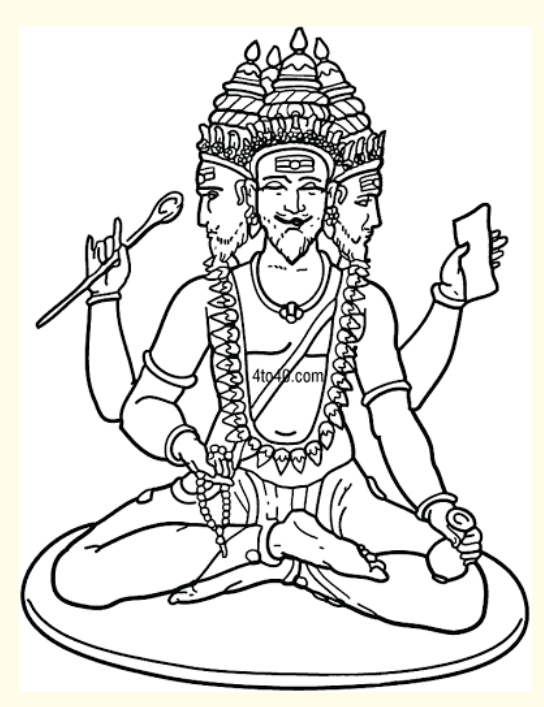

Figure 2: Lord Brahma.

(https://www.shutterstock.com/image-vector/this-image-god-hindureligion-lord-1382815166)

Vedas (Figure 3)

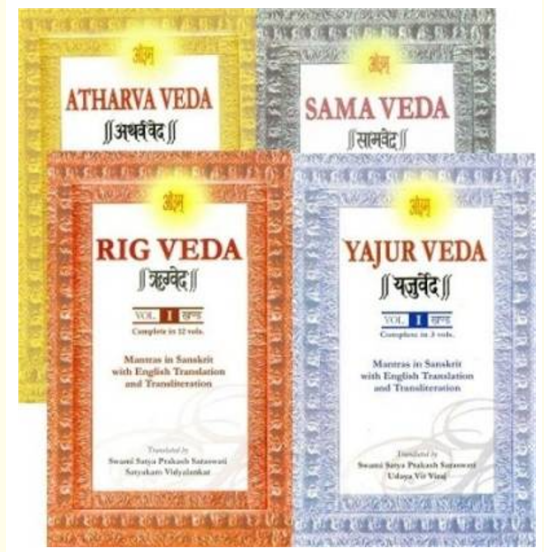

Figure 3: The four Vedas. (https://www.flipkart.com/ four-vedas-rig-veda-yajur-sama-atharva)

The Indian system of healing is believed to be based on the Vedas viz. Rig Veda, Yajur Veda, Sama Veda and Atharva Veda. Vedas are believed to be composed between 5000-1000 B.C. Rig Veda is the most popular and it is a collection of Sanskrit hymns and verses. It describes 67 plants and the use of natural remedies such as, exposure to sun rays. The Yajurveda consists of archaic prose mantras and partly verses borrowed from the Rig-Veda. References related to anatomical structures of animals as well as human beings are vastly available in this Veda. Medicinal properties of different herbs, their uses, and collection of drugs can also be found in Yajurveda. 81 medicinally useful plants are described in this. Sama Veda is considered as the Veda of holy songs or knowledge of melodies. Only few references related to Ayurveda are available in Sama Veda. Mainly it deals with the use of natural remedies like Sun, Air, Water, Fire etc. Atharva Veda contains detailed description of various aspects of Ayurvedic concepts, anatomical structures of human body, digestion and metabolism, blood circulation, diseases and their causative factors, preventive measures and treatment with herbs (293 plants). Ayurveda is considered as Upa veda of Atharva-Veda because of the enormous Ayurveda related resources contained in it [1].

\section{Brahma, Daksha (Figure 4)}

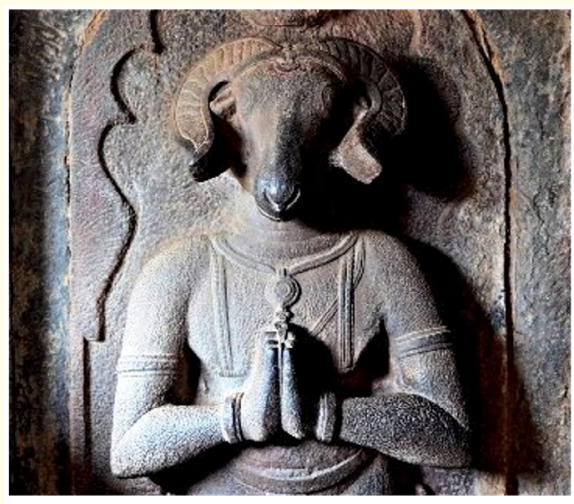

Figure 4: Daksha Prajapathi. (https://queennandini.wordpress. com/category/animal-of-the-day-challenge/page/2/)

Lord Brahma, creator of the universe passed on his knowledge of Ayurveda to his son- Daksha. Daksha who was amongst the first nine creations of Lord Brahma is known as a Prajapati because he was created for the purpose of populating the world. Daksha is also considered as God of procreation. The word Daksha literally means that one who is dexterous, able and honest. Daksha mar- 
ried Prasuti, the daughter of Svayambhu Manu. Sati the daughter of Daksha was married to Lord Shiva but it was not fully approved by Daksha. Daksha Prajapathi taught the science of Ayurveda to the Aswini Kumaras.

Ashwini Kumaras, Pushan (Figure 5,6)

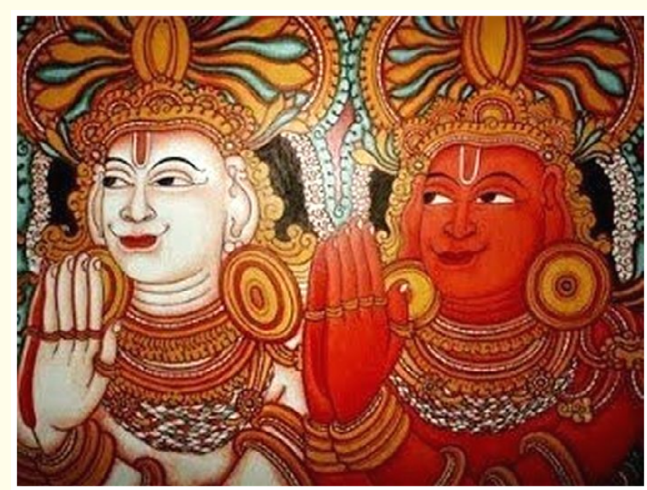

Figure 5: Ashwini Kumaras. (Wikipedia)

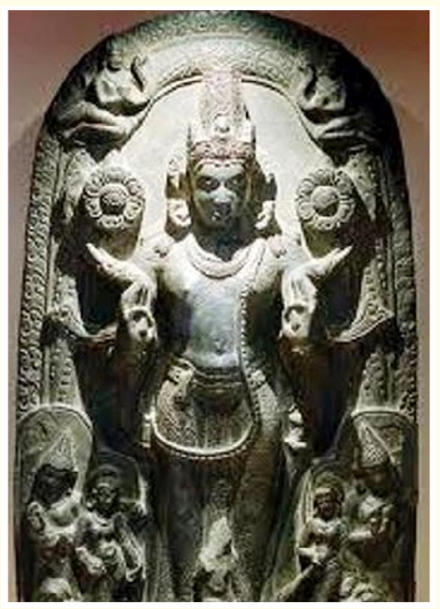

Figure 6: Pushan. (https://vedicgoddess.weebly.com/ bhakti-masala-blog/pushan-sun-god-more-gold-from-yogi-anandasaraswati)

Ashwini Kumaras are sons of God Sun and Suvarna who is the daughter of Vishvakarma. Ashwini Kumaras are considered as physicians of gods. They cured Indra, when he had fallen ill due to excessive soma drinking. Ashwini twins are well known for making old Chyavana Maharshi quite young and blessed him with long life. A narrative found in the Taittiriya Samhita explains that once Lord Shiva was excluded from a yagya organized by Daksha, his father-in-law. All the major deities of the universe were invited to this function. This is the famous Daksha's yagna where Sati sacrificed her life due to the insult meted to her husband. When Shiva came to know about Sati's death, he was enraged. He arrived at Daksha's palace and started destroying his yagya. Meanwhile, Pushan was sitting in the ceremony and eating the sweets and other offerings of the yagya. Furious, Lord Shiva punched him in the face and pushed all the teeth down the throat. He swallowed them. Indra was knocked down, Saraswati lost her nose, Mitra had his eyes gouged out. Daksha's head was severed and thrown to the Agnikunda. All the Gods fell at Shiva's feet and begged for mercy. Pacified Shiva restored the body parts of all the gods. Daksha's head was restored with a goat's head. But Pushan's teeth could not be restored because he swallowed them. Pushan remained tooth less and worshippers started offering him gruel and cooked ground food. Pushan is a Vedic solar deity. He is seen as riding in a chariot pulled by goats. In Vedic mythology, Pushan and Ashwins both marry Surya Savitri, the Sun Goddess. It is believed that Ashwins restored the teeth of Pushan, the earliest reference on dentistry [2].

Indra (Figure 7)

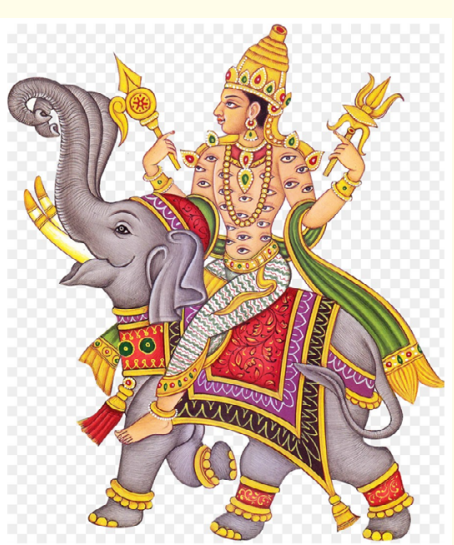

Figure 7: Indra. (http://www.sriramwallpapers.com/god/ lord-indra)

Aswini Kumaras taught the science of Ayurveda to Lord Indra. Indra is the king of Heaven along with his capital city Amaravati 
and the Devas. He is the deity of the heavens, lightning, thunder, storms, rains, river flows, and war. Indra is considered as the leader of devas and presides over them in Indraloka. And yet he is never worshipped because Indra is not the name of a person, but a position. One day of Lord Brahma is equal to 14 Kalpas. In turn one Kalpa is equal to 14 Manavantaras. One manvantara is equivalent to 43,20,00,000 human years. Each manvantara has a different Indra. The lineage of Ayurveda till the level of Lord Indra, appears to be in agreement in the opinions of all the major textbooks [3].

\section{Rishis approach Indra}

It was a time when many diseases haunted the living beings. A conclave of Rishis was held at the slopes of Himalayas and the topic of discussion was to find methods to eradicate ill health prevailing amongst human beings. The sages focused on diseases that had caused obstacles for achieving the four main goals of life -the four purușhārthas viz. Dharma (righteousness, moral values), Artha (ethical earning, prosperity), Kama (achieving meaningful wishes, pleasure, love, psychological values) and Moksha (spiritual values, liberation). It was decided to approach Lord Indra to obtain the knowledge of Ayurveda. Sage Bharadwaja volunteered to approach Indra. The rishi was capable of travelling fast to different terrains. The sage said that he will learn everything that Indra teaches and come back and teach the same to all (Figure 8).

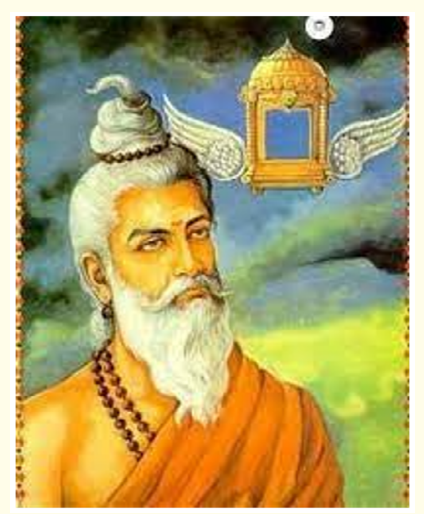

Figure 8: Rishi Bharadwaja. (https://www.facebook. com/680426415307037/photos/sages-from-the-hindu-scripturesbharadwaja)

After learning, Rishi Bharadwaja returned and taught the science to Punarvasu Athreya who has become one of the greatest teachers of Ayurveda. He had six desciples viz. Agnivesa, Bhela, Jatukarna, Parasa, Harita and Ksharapani. Punarvasu Athreya al- lowed discussions and Agnivesa, the most brilliant raised pertinent questions. One question was how to distinguish good and bad physicians. The teacher answered that there are two types of physicians- 1. Pranabhisara who promotes vital breath (saves life) and destroys diseases 2 . Rogabhisara who promotes diseases and destroys vital breath (life). The teacher continued to enumerate the qualities of physicians.

\section{Qualities of good physicians are}

- Kuleena (born in noble families)

- Paryavadata shruta (well read)

- Paridrushta karma (has practical experience)

- Daksha (disciplined, skillful)

- $\quad$ Suchi (hygienic)

- Jitahasta (expert hands)

- Jitaatmana (control over mind)

- Sarva upakaranavanta (having all the equipments)

- Sarvendriya upapanna (healthy sense organs)

- Prakrutijna (acquainted with natural manifestations)

- Paratipattijna (presence of mind) (29 $9^{\text {th }}$ chapter Charaka samhita-dasaprana ayataneeya adhyaya suthrasthana).

The six desciples based on their understanding prepared their own treatises and presented before the experts including Punarvasu Atreya. The version of Agnivesa was later rewritten by Charaka, which has become charaka Samhita (Figure 9).

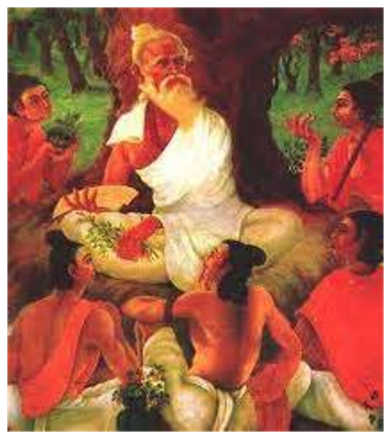

Figure 9: Punarvasu-Atreya. (https://www.oshonews. com/2017/01/24/sarita-amazing-ayurveda/ punarvasu-atreya/)

Susruta samhita provides another version of the origin of Ayurveda. When diseases spread among human beings, Susruta 
along with other sages approached King Divodasa of Benares who is considered as the reincarnation of Dhanwantari. According to legend, the gods and the demons sought the elixir amrita by churning the milky ocean and Dhanvantari rose out of the waters bearing a cup filled with the elixir. King Divodasa agreed to teach Ayurveda to the rishis. Divodasa (Dhanvantari) stated that Brahma composed the Ayurveda even before he created mankind, forming one of the upangas of the Atharvaveda in 100,000 verses arranged in 1,000 chapters, which was not easy for the restricted intelligence of men to learn within their short span of life. So Dhanvantari complied with the sages' request, recast Brahma's Ayurveda into 8 divisions - shalya (Surgery), shalakya (Cephalic Diseases including ENT and Dentistry), kayachikitsa (General Medicine), bhutavidya (Psychiatry), kaumarabhrtya (Obstectrics/Pediatrics), agadatantra (Toxicology), rasayanatantra (Rejuvenation Therapy), vajikaranatantra (Aprodisiac therapy) and began teaching within the framework of pratyaksa (perception), agama (authoritative scripture), anumana (inference) and upamana (analogy). Divodasa gave importance to surgery in his school. Susruta asked questions and Divodasa answers and the compilation was done by Susrutha. This is later known as Susrutha Samhita according to which the lineage is as follows: Brahma, Prajapathi, Aswinikumaras, Indra, Dhanwanthari (Divodasa). Another version is that Divodasa learned Ayurveda from Rishi Bharadwaja who learned it from Indra.

Sage Kashyapa is one the ancient rishis who authored the treatise on Ayurveda, known as Kashyap Samhita which narrates the origin of Ayurveda with slight difference. Before creating human beings, Brahma originated Ayrveda and which was passed on to Aswinikumars. They have passed the knowledge to Indra who taught Ayurveda to four sages viz. Kasyapa, Vasishta, Atri and Bhrigu. In turn they have taught the divine science to their children and disciples. The origin of Ayurveda can be summarized as follows: $[4,5]$.

\section{Conclusion}

The science of Dentistry and Medicine in India has a profound history which can be traced to the Vedas and hence the origin is considered as divine. The lineage from Brahma to Indra is similar in all the texts. Further the knowledge of dentistry and medicine got propagated through different channels.

\section{Bibliography}

1. https://www.nhp.gov.in/origin-of-ayurveda_mtl

2. https://en.wikipedia.org/wiki/Ashvins

3. https://www.worldhistory.org/Indra/

4. Jaggi O P. "Indian System of Medicine". Atmaram and Sons, Delhi, India 4.1 (973): 1-6.

5. Choksey K M. "Dentistry in Ancient India”. Popular Book Depot, Bombay (1953): 1-8.

\section{Assets from publication with us}

- Prompt Acknowledgement after receiving the article

- Thorough Double blinded peer review

- Rapid Publication

- Issue of Publication Certificate

- High visibility of your Published work

Website: www.actascientific.com/

Submit Article: www.actascientific.com/submission.php Email us: editor@actascientific.com

Contact us: +919182824667 